\title{
Participatory design of (built) learning environments
}

Citation for published version (APA):

Konings, K. D., \& McKenney, S. (2017). Participatory design of (built) learning environments. European Journal of Education, 52(3), 247-252. https://doi.org/10.1111/ejed.12232

Document status and date:

Published: 01/09/2017

DOI:

10.1111/ejed.12232

Document Version:

Publisher's PDF, also known as Version of record

Document license:

Taverne

Please check the document version of this publication:

- A submitted manuscript is the version of the article upon submission and before peer-review. There can be important differences between the submitted version and the official published version of record.

People interested in the research are advised to contact the author for the final version of the publication, or visit the DOI to the publisher's website.

- The final author version and the galley proof are versions of the publication after peer review.

- The final published version features the final layout of the paper including the volume, issue and page numbers.

Link to publication

\footnotetext{
General rights rights.

- You may freely distribute the URL identifying the publication in the public portal. please follow below link for the End User Agreement:

www.umlib.nl/taverne-license

Take down policy

If you believe that this document breaches copyright please contact us at:

repository@maastrichtuniversity.nl

providing details and we will investigate your claim.
}

Copyright and moral rights for the publications made accessible in the public portal are retained by the authors and/or other copyright owners and it is a condition of accessing publications that users recognise and abide by the legal requirements associated with these

- Users may download and print one copy of any publication from the public portal for the purpose of private study or research.

- You may not further distribute the material or use it for any profit-making activity or commercial gain

If the publication is distributed under the terms of Article $25 \mathrm{fa}$ of the Dutch Copyright Act, indicated by the "Taverne" license above, 


\section{Participatory design of (built) learning environments}

\section{1 | INTRODUCTION}

Educational policy and curricula are developing continuously to prepare students for a rapidly changing world. In addition to disciplinary developments, recent curriculum reform efforts focus frequently on the development of collaborative skills and lifelong learning attitudes, as well as on the necessary skills to participate in decision-making in society (Van Merriënboer \& Kirschner, 2013). For example, national curriculum policy changes have been promulgated to improve the quality of teaching and learning through assessments (e.g., Assessment is for Learning in Scotland (www.gov.scot/Resource/Doc/69582/0017827.pdf)), develop the subject area (e.g., 21st Century Science in the UK (www.gov.scot/Resource/Doc/69582/0017827.pdf)), or prepare learners for changing labour markets (e.g., Education 2032 in the Netherlands (http://onsonderwijs2032.nl/wp-content/uploads/2016/04/160412)). Underpinning any curriculum change is a vision about education.

\section{2 | IMPLEMENTING CHANGE REQUIRES AN INFRASTRUCTURE}

To be implemented successfully, the vision underlying curriculum change must align with other elements of the educational system, including examinations and teachers' professional development (McKenney, Nieveen, \& van den Akker, 2006). Penuel (2015) introduced the concept of infrastructuring to promote transformation and equity in research that blend interventionist goals with a focus on implementation. Infrastructuring includes attention to how and when local actors transform policies and practices through their enactment (McKenney, 2017). By drawing on concepts from participatory design (Le Dantec \& DiSalvo, 2013; Star \& Ruhleder, 1996) and linking them with relevant educational research findings (Hopkins \& Spillane, 2015; Hopkins, Spillane, Jakopovic, \& Heaton, 2013), Penuel (2015) makes a compelling case for attending to the practice of infrastructuring. This call is heeded in this issue of the Journal by articulating what we know and need to learn about organising for agency and developing reliable working infrastructures for school-based innovation.

Also important, but much less widely recognised, is the alignment of the educational vision with the physical learning environment, i.e., the building, as a space for learning, affects if and how the pursued educational goals can be reached (Nordquist \& Laing, 2015). Students prefer physical learning spaces that are related to their learning activities (Beckers, Van der Voordt, \& Dewulf, 2016a, 2016b). The classroom design impacts their perceptions of quality of teaching and their level of engagement (Imms \& Byers, 2017), as well as the social climate and attendance which eventually affects achievement (Maxwell, 2016). Just as changes in the aims of education should go hand in hand with adapting teaching methods and the tools used (Conner \& Sliwka, 2014; Stukalina, 2010), changes in educational vision require commensurate changes related to the physical environments in which that vision will come to life.

Clear policies about alignment between school buildings and offered curricula are often missing. The implementation of educational innovation depends on many factors, including the physical environment in which the instruction takes place. For example, research has shown that even the placement of doors, windows and electrical sockets can influence pedagogical decisions about the use of technology in schools (Tondeur, De Bruyne, Van den Driessche, McKenney \& Zandvliet, 2015). Instructional models have only very recently started to explore the impact of the physical learning environment on learning (Choi, Van Merriënboer, \& Paas, 2014). Many schools and campuses are 'more or 
less living museums of past concepts of curricula and learning' (Nordquist \& Laing, 2014, p. 556). Moreover, when designing new learning spaces, architects tend to use their own, often out-dated concepts of learning and teaching (Nordquist \& Sundberg, 2013). Meanwhile, it remains a challenge for educational leaders to push forward the development of new educational building projects that are driven by their vision, or, ideally, their vision of the learning futures we wish to create (Watson, 2007).

\section{3 | THE POWER OF PARTICIPATORY DESIGN}

Greater collaboration is needed between educational leaders and architects in the design process (Nordquist \& Sundberg, 2013; Watson, 2007), whilst some argue that the whole intellectual community, including teachers and students, should be involved in decision-making regarding the management of the educational environment (Ellis \& Goodyear, 2016; Stukalina, 2010; Woolner, Hall, Wall, \& Dennison, 2007). It is questionable to design innovations that are usable, sustainable, and scalable in classrooms for teachers without their participation (Fishman \& Krajcik, 2003; Kali, McKenney, \& Sagy, 2015). Similarly, there have been calls for greater student involvement in the design process (Könings, Seidel, \& Van Merriënboer, 2014). Students are active members of the intellectual community and should be invited to contribute to the development of their educational environment, thus increasing their sense of ownership and motivation (Stukalina, 2010; Woolner et al., 2007). Although it is acknowledged that student voices must be taken more seriously, this is still not common practice in mainstream policies (Downes, 2013). The voices and views of children and young people have occasionally been heard with the intention of involving them in the design of school and education (Burke \& Grosvenor, 2003), but there has been little evidence of change in the design of school buildings and curricula. There is a need for 'higher levels of engagement of staff, administrators and students in defining the briefs for the design of new kinds of education environments' (Nordquist \& Laing, 2015, p. 1).

Participatory design is known to be a valuable approach for instructional design (Cook-Sather, Bovill, \& Felten, 2014; Giacquinta, 1998; Könings et al., 2014). Teachers, educational designers and students bring together their expertise and experiences to jointly design instruction. This issue of the Journal expands the approach of participatory design to include the architecture of the physical spaces in which education takes place. Architects, policy makers and teachers, as well as students, are important stakeholders whose views must be included in the (re)design process of physical learning environments.

\section{I TOOLS AND CONCEPTS FOR THE PARTICIPATORY DESIGN OF BUILT LEARNING ENVIRONMENTS}

In this issue of the Journal, five articles and two commentaries shed light on multidisciplinary collaboration related to the developments of physical learning environments. Whilst some articles emphasise the impact of physical space on learning, others focus on supporting participatory design processes. In this Editorial we show how, as a set, they contribute tools and concepts to enrich our understanding of the participatory design of (built) learning environments. Figure 1 offers a visual representation of the contents, followed by explanations of each article's contribution to the overall set.

How might the built learning environment process flow? The grey boxes on the left side of Figure 1 represent an overall process for considering the built learning environment. Here, the frequently used and often cited four-component instructional design (4C/ID) model (Van Merriënboer \& Kirschner, 2013) is taken as a starting point to design and realise appropriate physical spaces. It is described in the article by Van Merriënboer, McKenney, Cullinan, and Heuer (2017, pp. 253-267). They explain why the educational goals require appropriate physical spaces, which kinds of spaces support specific learning processes, and how these can be developed in close collaboration with learners. This article contributes particularly to a view of the overarching process and gives examples of two school design scenarios.

What can enrich the instructional design process? Many factors influence the instructional design process, not least of which is need for the expertise and guidance of non-professional designers (such as teachers) in design activities. 


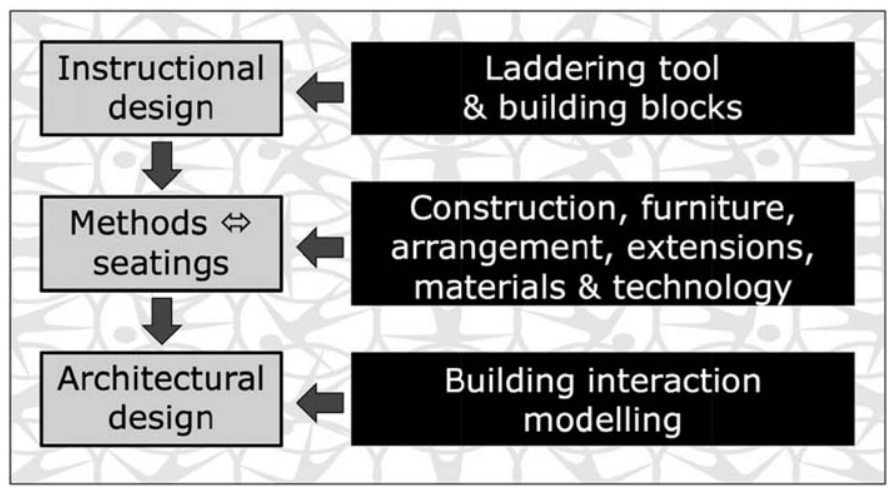

FIGURE 1 Tools and concepts for the participatory design of built learning environments

Tools can help. The top black box of Figure 1 represents theory-based tools for optimising the participatory design process. In their article, Janssen, Könings, and Van Merriënboer (2017, pp. 268-279) present two tools that foster mutual learning and enhance the quality and usability of participatory educational design products. The laddering tools and the building block tool are based on goal systems and modularity literature, respectively.

What are key considerations for methods and seatings? The middle black box of Figure 1 emphasises key considerations for the use of space during learning, namely hardware, software, setting, situation and agency. They stem from a retrospective analysis conducted by Tondeur, Herman, De Buck, and Triquet (2017, pp. 280-294). Their article describes architectural and infrastructural developments of classrooms in the last 55 years. They note the impact of learning spaces on how teachers work with students and how teachers experience different physical environments throughout their careers.

Which architectural design pathways yield promising results? Whilst user participation is recognised as a key element in the architectural design of schools, discrepancies persist between the perspectives of the architects and engineers, those who construct school buildings, and those who will eventually use them, school management, teachers, and students. Technology-based information tools can help by modelling scenarios. The bottom black box of Figure 1 represents a specific approach for doing so, called building interaction modelling. As explained in the article by Koutamanis, Heuer, and Könings (2017, pp. 295-305), this approach views the broader lifecycle of school design and considers users as a permanent, key presence in the initiation, development, management and evaluation of their own environment.

How can the active engagement of various stakeholders be stimulated in the design of built learning environments? Whilst this is considered by many to be extremely important, it is quite rare. In Figure 1, stakeholder participation, which affects each aspect of the process, is represented by the background. Könings, Bovill, and Woolner (2017, pp. 306-317) describe multiple pathways for shaping the participatory design process with varied stakeholders to realise the instructional and physical learning environment. After reviewing ideal forms of stakeholder involvement as described in four separate teams, this article synthesises core considerations into a new interdisciplinary model of participatory building design in education.

In addition, two commentaries on the articles enrich our understanding of important facets of or the participatory design of built learning environments. Given his background in educational technology and design-based research as a change-driven, solution-oriented methodology in schools and museums, Hall draws our attention to the school building design as 'the third teacher' (2017, pp. 318-326). After a thorough reflection on the articles in this issue, he shares his ideas for advancing the research policy agenda by suggesting an ontology of emergent, key design sensitivities: space, engagement, aestheticity and media (SEAM). In contrast, Nordquist and Watter (2017, pp. 327-335) leverage their expertise in the field of how space impacts on learning. Nordquist has been in charge of the Future Environment Learning Project at Karolinska Institutet (Sweden), as well as the redevelopment and production of more than 400 physical learning environments. Nordquist \& Watter make six comments on different aspects, ranging from the added value of involving faculty, the need to look beyond the walls of the classroom to also support informal technologyenabled learning, educational sustainability of space, to suggesting the extension of the choir of voices with external benchmarking. 
The articles in part I of this issue are the outcome of a funded research and networking project in which Dutch and British experts on participatory design from different disciplines exchanged ideas and experiences. Educational designers, school pupils, teachers and teacher educators, architects and architect educators shared their expertise and analysed successful examples of the participatory design of school environments. Consistent with the view that varied stakeholder perspectives are crucial, the five main contributions were written in multidisciplinary author teams.

Part II of this issue includes unsolicited articles submitted to the Journal. It begins with an article by Marianne Dæhlen which investigates the importance of school motivation, self-efficacy and the characteristics of students and their families for completing school and examines students in the vocational and academic tracks separately. It is guided by the following question: Do students who obtain an upper secondary diploma have greater motivation and stronger beliefs about their abilities than those who choose to leave school early? When adjusting for background characteristics, the results indicated no, or a relatively low, relationship between school motivation/self-efficacy and completion. The most predictable variable is prior school performances, particularly for students in the vocational track.

The second article by Alvaro Choi \& Jorge Calero on the distribution of skills among the European adult population and unemployment: A comparative approach addresses two questions. First, it estimates the importance of the level of skills and education for the probability of being unemployed, disentangling the extent of the effects of human capital and signalling theories of education; and, second, it provides evidence of the impact of inequalities in the individuals' previous socioeconomic and cultural background on the probability of being unemployed.

The third article, Competition, student sorting and performance gains in local education markets: The Dutch secondary sector, by Sofie Cabus \& Ilja Cornelisz examines the implications of competition among Dutch secondary schools regarding the sorting of students by performance levels in schools at the beginning of secondary education; and performance gains in the secondary school career. The results indicate that, with increasing competition, relatively more schools target the group of high-achieving students. Hence, schools will have to enrol more 'students at the margin' to ensure sufficient enrolment rates.

The fourth article on University research and the creation of spin-offs: The Spanish case by Isabel RománMartínez, María-Elena Gómez-Miranda \& Juan Sánchez-Fernández analyses the relationship between research and the creation of spin-offs in Spain and identifies the factors which can be linked to the level of technology used by these companies. It analysed two groups of universities, correlating their number and technological nature with the research potential of the parent university, the general economic situation and the assistance received in creating this type of company. A positive relation was found between the creation of university spin-offs and the average number of projects achieved by the university. In addition, their technological nature is positively related to the number of patents awarded to the university.

\section{ACKNOWLEDGMENTS}

The project reported on in Part I of this issue was co-funded by the Netherlands Organisation for Scientific Research (Humanities) and the Arts and Humanities Research Council (Grant Number 318-98-104).

Karen D. Könings ${ }^{1}$ and Susan McKenney ${ }^{2}$

${ }^{1}$ Department of Educational Development \& Research, Faculty of Health, Medicine and Life Sciences, Maastricht University, Maastricht, The Netherlands

${ }^{2}$ Department of Teacher Professional Development, Faculty of Behavioural, Management and Social Sciences, University of Twente, Enschede, The Netherlands 
Funding information Netherlands Organisation for Scientific Research; Arts and Humanities Research Council, Grant/Award Number: 318-98-104

\section{REFERENCES}

Beckers, R., Van der Voordt, T., \& Dewulf, G. (2016a). Learning space preferences of higher education students. Building and Environment, 104, 243-252.

Beckers, R., Van der Voordt, T., \& Dewulf, G. (2016b). Why do they study there? Diary research into students' learning space choice in higher education. Higher Education Research \& Development, 35, 142-157.

Burke, C., \& Grosvenor, I. (2003). The school l'd like. Children and young people's reflections on an education for the 21st century. London: RoutledgeFalmer.

Choi, H. H., Van Merriënboer, J. J., \& Paas, F. (2014). Effects of the physical environment on cognitive load and learning: Towards a new model of cognitive load. Educational Psychology Review, 26, 225-244.

Conner, L., \& Sliwka, A. (2014). Implications of research on effective learning environments for initial teacher education. European Journal of Education, 49, 165-177.

Cook-Sather, A., Bovill, C., \& Felten, P. (2014). Engaging students as partners in teaching and learning: A guide for faculty. San Francisco, CA: Jossey-Bass.

Downes, P. (2013). Developing a framework and agenda for students' voices in the school system across Europe: From diametric to concentric relational spaces for early school leaving prevention. European Journal of Education, 48, 346-362.

Ellis, R. A., \& Goodyear, P. (2016). Models of learning space: Integrating research on space, place and learning in higher education. Review of Education, 4, 149-191.

Fishman, B. J., \& Krajcik, J. (2003). What does it mean to create sustainable science curriculum innovations? A commentary. Science Education, 87, 564-573. doi:10.1002/sce.10088

Giacquinta, J. B. (1998). Seduced and Abandoned: some lasting conclusions about planned change from the Cambire School Study. In International handbook of educational change (pp. 163-180). Springer Netherlands.

Hall, T. (2017). Architecting the 'third teacher': Solid foundations for the participatory and principled design of schools and (built) learning environments. European Journal of Education, 52, 318-326.

Hopkins, M., \& Spillane, J. P. (2015). Conceptualizing relations between instructional guidance infrastructure (IGI) and teachers' beliefs about mathematics instruction: Regulative, normative, and cultural-cognitive considerations. Journal of Educational Change, 16, 421-450.

Hopkins, M., Spillane, J. P., Jakopovic, P., \& Heaton, R. M. (2013). Infrastructure redesign and instructional reform in mathematics. Elementary School Journal, 114, 200-224.

Imms, W., \& Byers, T. (2017). Impact of classroom design on teacher pedagogy and student engagement and performance in mathematics. Learning Environments Research, 20, 139-152.

Janssen, F. J. J. M., Könings, K. D., \& van Merriënboer, J. J. G. (2017). Participatory educational design: How to improve mutual learning and the quality and usability of the design? European Journal of Education, 52, 268-279.

Kali, Y., McKenney, S., \& Sagy, O. (2015). Teachers as designers of technology enhanced learning. Instructional Science, 43, 173-179.

Könings, K. D., Bovill, C., \& Woolner, P. (2017). Towards an interdisciplinary model of practice for participatory building design in education. European Journal of Education, 52, 306-317.

Könings, K. D., Seidel, T., \& Van Merriënboer, J. J. G. (2014). Editorial: Participatory design: Integrating perspectives of students, teachers, and designers. Instructional Science, 42, 1-9.

Koutamanis, A., Heuer, J., \& Könings, K. D. (2017). A visual information tool for user participation during the lifecycle of school building design: BIM. European Journal of Education, 52, 295-305.

Le Dantec, C. A., \& DiSalvo, C. (2013). Infrastructuring and the formation of publics in participatory design. Social Studies of Science, 43, 241-264.

Maxwell, L. E. (2016). School building condition, social climate, student attendance and academic achievement: A mediation model. Journal of Environmental Psychology, 46, 206-216.

McKenney, S. (2017). Infrastructuur voor de professioneel ontwikkeling van docenten [Infrastructuring teacher growth]. Enschede, The Netherlands: University of Twente.

McKenney, S., Nieveen, N., \& van den Akker, J. (2006). Design research from the curriculum perspective. In J. Van den Akker, K. Gravemeijer, S. McKenney, \& N. Nieveen (Eds.), Educational desigresearch (pp. 67-90). London: Routledge. 
Nordquist, J., \& Laing, A. (2015). Designing spaces for the networked learning landscape. Medical Teacher, 37, $337-343$.

Nordquist, J., \& Sundberg, K. (2013). An educational leadership responsibility in primacy care: Ensuring the physical space for learning aligns with the educational mission. Education for Primary Care, 24, 45-49.

Nordquist, J., \& Watter, M. (2017). Participatory design beyond borders. European Journal of Education, 52, 327-335.

Penuel, W. (2015). Infrastructuring as a Practice for Promoting Transformation and Equity in Design-Based Implementation Research. Keynote presented at the annual meeting of the International Society for Design and Development in Education. September 22-25, Boulder, CO.

Star, S. L., \& Ruhleder, K. (1996). Steps toward an ecology of infrastructure: Design and access for large information spaces. Information Systems Research, 7, 111-134.

Stukalina, Y. (2010). The management of integrated educational environment resources: The factors to be considered. European Journal of Education, 45, 345-361.

Tondeur, J., De Bruyne, E., Van den Driessche, M., McKenney, S., \& Zandvliet, D. (2015). The physical placement of classroom technology and its influences on educational practices. Cambridge journal of education, 45(4), 537-556.

Tondeur, J., Herman, F., De Buck, M., \& Triquet, K. (2017). Classroom biographies: Teaching and learning in evolving material landscapes (c. 1960-2015). European Journal of Education, 52, 280-294.

Van Merriënboer, J. J. G., \& Kirschner, P. A. (2013). Ten steps to complex learning: A systematic approach to four-component instructional design (2nd Rev. ed.). New York: Routledge.

Van Merriënboer, J. J. G., McKenney, S., Cullinan, D., \& Heuer, J. (2017). Aligning pedagogy with physical learning spaces. European Journal of Education, 52, 253-267.

Watson, L. (2007). Building the future of learning. European Journal of Education, 42, 255-263.

Woolner, P., Hall, E., Wall, K., \& Dennison, D. (2007). Getting together to improve the school environment: User consultation, participatory design and student voice. Improving Schools, 10, 233-248. 